\title{
COMPOSITION, STRUCTURE AND FLORAL DIVERSITY OF FOREST COMMUNITIES OF ACHANAKMAR- AMARKANTAK BIOSPHERE RESERVE :A COMPARISON AND CONSERVATION IMPLICATION
}

\author{
Rashmi Agrawal ,Bhavana Dixit, *Lalji Singh , and B. M. Ojha \\ Department of Forestry Gurughasidas Vishwavidyalaya, Bilaspur,C.G.INDIA \\ *Department of Forestry I.G.K.V. Raipur C.G. INDIA \\ drrashmi_agarwal@yahoo.co.in \\ dixit1968@yahoo.com
}

\begin{abstract}
The core region of Achanakmar- Amarkantak Biosphere Reserve falls in Chhattisgarh State (India) and lies between lat.22 ${ }^{0} 15^{\prime}$ to $20^{0} 58^{\prime} \mathrm{N}$ and long. $81^{0} 25^{\prime} \mathrm{N}$ to $82^{0} 5^{\prime}$ 'E. Shorea robusta Gaertn F. (sal) is the dominant species occurring in this region. The present study deals with the comparative account of composition and diversity of pure Shorea robusta forest and degraded mixed moist forest of Achanakmar- Amarkantak Biosphere Reserve.Based on the repeated reconnaissance of the area, three representative sites of size 1 hac. in pure sal forest was selected for two growth strata stages eg.upper story(trees )under story(,saplings and seedlings ). The forest vegetation was analyzed using 10 randomly placed quadrate (each $10 * 10 \mathrm{~m})$ within the representative sites. The vegetation data were quantitavely analyzed for frequency, density, abundance and Importance value index and various indices of alpha and beta diversity. The pure Shorea robusta forest showed high density and basal cover of trees $\left(1233 \mathrm{stem} \mathrm{ha}^{-1}\right.$, basal cover $36.36 \mathrm{~m}^{2} \mathrm{ha}^{-1}$ )and under story vegetation (density 1575 stem $\mathrm{ha}^{-1}$, basal cover $1.85 \mathrm{~m}^{2} \mathrm{ha}^{-1}$ ). The degraded mixed moist deciduous forest sites represents the degraded stage having low density of trees and basal cover( 633 stem ha $^{-1}$ basal cover $\left.32.82 \mathrm{~m}^{2} \mathrm{ha}^{-1}\right)$ and under story vegetation (density 918 stem ha $^{-1}$, basal cover $0.37 \mathrm{~m}^{2} \mathrm{ha}^{-1}$ ). The total number of species was high in pure Shorea robusta forest as compared to degraded mixed moist deciduous forest.

Similarly plant diversity was also high in pure Shorea robusta (sal) forest for trees and understory(2.82;2.92 Shanon index;4.76;2.32 richness index ,0.99;1.01 equitability ,0.21;0.22 concentration of dominance,5.78;8.82 beta diversity)respcectively than on degraded mixed moist deciduous forests for trees and understory(1.99;2.44 Shanon index;3.48;1.43richness index , 0.78;1.04 equitability index, $0.39 ; 0.26$ concentration of dominance, $8.20 ; 11.93$; beta diversity)respcectively..The climatic condition of the region supported the regeneration of Shorea robusta (sal) and its associates in the climax formation over a long successional process. The study focus the comparison and conservation implication of this biosphere reserve.
\end{abstract}

Key words: Bioshere Reseve,Composition, Floral diversity, Structure and Succession.

\section{INTRODUCTION}

While biodiversity loss is a global phenomenon, its impact may be greatest in the tropics where the majority a species are distributed. This long recognized pattern of increasing diversity towards the tropics is exemplified in tropical forest, which take up less than 2 percent a the earth's surface, but contain upwards a 50 percent of its biodiversity. (Howkins,2001) In order to effectively mitigate biodiversity loss, grater investment of conservation attention is required in tropical region where there is the more to lose. Broadreaching global legislation may provide an impact for such investment. One important example is the convention on biological diversity (CBD), under which 190 signatory nations have ambitiously committed themselves to "achieve, by 2010 levels".( UNEP, 2002)Assessing - Progress towards this important goal requires data on the status and trend in biodiversity for a country or region.

Proceedings of the International Forestry and Environment Symposium 2010 of the Department of Forestry and Environmental Science, University of Sri Jayewardenepura, Sri Lanka. 
Tree species diversity in the tropics varies dramatically from place to place ( Pitmen et al. 2002). Much attention has been give to tropical forests due to their species richness (whitmore,1984) high standing biomass ( Bruening, 1983) and greater productivity (Jordon, 1983).

\section{MATERIAL AND METHOD}

\section{STUDY AREA}

The Achanakmar-Amarkantak Biosphere Reserve is one of the premium biosphere reserve in India. The reserve covers a huge area of $3835.5189 \mathrm{sq} . \mathrm{km}$. and it falls in almost northern part of bio-geographic zone of 6 and Bio-geographic province 6a ( Deccan peninsula, Central highlands). About $68.10 \%$ out of the total area of this reserves lies in the Bilaspur district in Chhattisgarh. The area of the Achanakmar-Amarkantak Biosphere Reserve is considered as one of the major watershed at peninsular India. It separates the rivers that drain in to the Arabian sea and Bay of Bengal. The reserve is also unique on being the source of there major river systems like Narmada, Johilla and Sone of the Ganga basin.

Study area is described in detail by (EPCO,1999). The Achanakmar - Amarkantak Biosphere Reserve is located between $22^{\prime} 15^{\prime}$ 'to $22^{\prime} 58^{\prime} \mathrm{N}$ latitude and $81^{\prime} 25^{\prime}$ to $82^{\prime}{ }^{\prime}$ ' E longitude. The land use analysis made by RSAC, Bhopal indicates that $63.19 \%$ of the area is occupied by the forest. It can be classified in to Northern tropical moist deciduous and southern dry mixed deciduous forest. The Reserve is highly rich in biodiversity, both flora and fauna and is also endowed with several rare and endangered species. It has rich diversity of medicinal and aromatic plant. However, Increased biotic interference during the last two decades has eroded the structure and diversity of these forest. Major problems in the area are illicit grazing by cattle, expansion of agriculture , increased mining, over exploitation of NTFP's and medicinal plants. The present study focuses on the relationship of environment to the composition, structure and diversity of forest communities of the Achanakmar- Amarkanantak Biosphere Reserve.

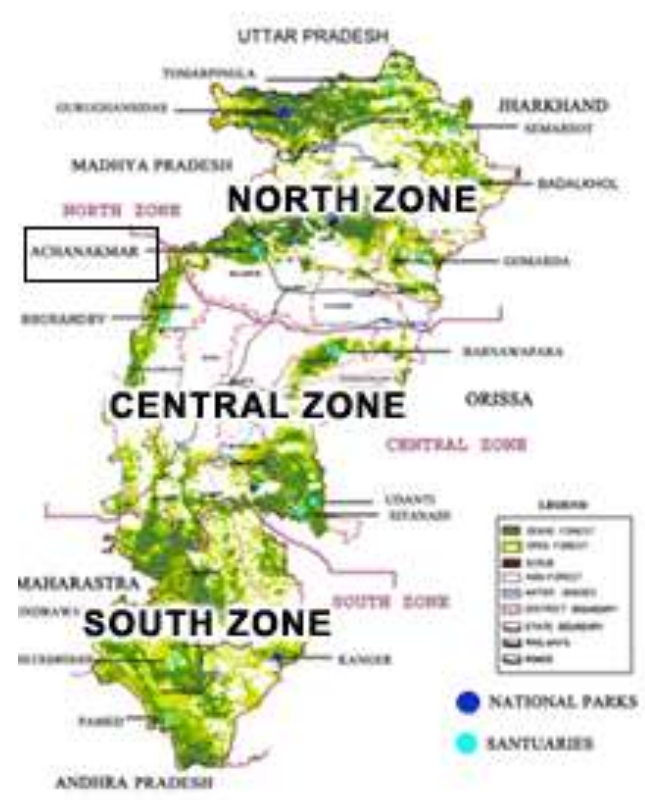

\section{MAP OF ACHANAKMAR -AMARKANTAK BIOSPHERE RESERVE}

The climate of the reserve is tropical and the year is distinctly divisible in to winter ( NovemberFebruary), summer ( April-June) and a warm rainy season ( July-September), Mean monthly minimum temperature within the annual cycle ranges from $10.9^{\circ}$ to $25.6^{\circ} \mathrm{C}$ and mean monthly maximum temperature from 24.1 to $42 .{ }^{\circ} \mathrm{C}$. The annual rainfall average is $1322 \mathrm{~mm}$. ( mean monthly range is $6.63 \mathrm{~mm}$ to $359.88 \mathrm{~mm}$ ) of which about $85 \%$ occurs during the period mid June to September.

The soil of the study area that varies greatly depending upon the parent rocks and topography is red lateritic, nutrient poor ( lacking $\mathrm{N}$ and $\mathrm{P}$ ) and characterized by excessive amounts of iron oxide ( Prakash, 1992) 


\section{SURVEY}

Based on repeated reconnaissance of the area, representative sites of pure sal forest and miscellaneous moist deciduous forest were selected for the present study. In each forest type the observations were recorded on three experimental plots, each $100 \mathrm{~m} \times 100 \mathrm{~m}$ in area .The pure sal forest represents the climax, dense and reserve forest types whereas miscellaneous moist forest represents the degraded forest.

The forest vegetation was analyzed using 10 randomly placed quadrates (each $10 \times 10 \mathrm{~m}$ in size) within the representative 1 ha plot on each of the three plots. The size and number of quadrates needed were determined using the species area curve(Misra 1968) and the running mean method (Kershaw 1973 ). In each quadrate, dbh of each mature individual $(>9.6 \mathrm{~cm}$ $\mathrm{dbh}$ ) was measured in the center of each $10 \times 10 \mathrm{~m}$ quadrate, a $2 \times 2 \mathrm{~m}$ area was marked for enumeration of saplings (individuals $3.2 \mathrm{~cm}$ to $<9.6 \mathrm{~cm}$ dbh ) and seedlings (individuals < $3.2 \mathrm{~cm}$ diameter but $<30 \mathrm{~cm}$ height ). In the present study the saplings and seedlings are pooled under the category of undestroyed vegetation. Stem diameter of mature and saplings individuals were measured at $1.37 \mathrm{~m}$ from the ground and for seedlings it was measured at 10 $\mathrm{cm}$ above the ground. The vegetation data were quantitatively analyzed for frequency, density and abundance. ( Curtis \& Mclntosh 1950 ). An importance value inbox (IVI) was calculated as the sum total of relative frequency, relative density and relative dominance (Phillips 1959)

The alpha diversity and its components, i.e. species richness (Margalef index) and evenness (Whittaker index) were calculated for each plot. Beta diversity was calculated for each plot to represent the degree of habitat heterogeneity. These indices were calculated following Sagar and Singh (1999). Shanon-Wiener ,1963 information function was used for species diversity
$\mathrm{H}^{\prime}=$ pi log pi
where $\mathrm{Pi}$ is the proportion of basal cover/ density of the species (ni) in the total of the community $(\mathrm{N})$. We used a factor of 3.3219 to convert $\log _{10}$ to $\log _{2}$ ( Smith 1974).

Concentration of dominance was measured by Simpson's index (Simpson 1949)

$$
\mathrm{Cd}=(\mathrm{Ni} / \mathrm{N}) 2 \quad \text { where } \mathrm{Ni} \text { and } \mathrm{N} \text { are same as above. }
$$

Equitability (e) was calculated following pielou (1966) , as:

$\mathrm{E}=\mathrm{H}^{\prime} / \mathrm{S}$ where $\mathrm{H}^{\prime}=$ Shannon index and $\mathrm{S}=$ number of species

Species richness (d) was calculated following Marglef (1958) as:

$\mathrm{D}=(\mathrm{S}-1) / \mathrm{N}$ where $\mathrm{S}=$ total number of species and $\mathrm{N}$ - total basal cover/total density of all species.

Beta diversity was calculated according to the formula given by Whittaker (1972):

$\mathrm{Bd}=\mathrm{Sc} / \mathrm{S}$

where $\mathrm{Sc}=$ total number of species in the two sites (i.e. pure sal forest site and degraded moist deciduous forest site ) and

$\mathrm{S}=$ average member of species per site.

\section{RESULT AND DISCUSSION}

\section{SPECIES DIVERSITY}

A total of 101 species that belongs to 46 families were recorded from study area. The result showed that the greater number of species were recorded in the pure sal forest ( 26 families and $66 \mathrm{spp}$ ) than the degraded moist deciduous forest (20 families, 41 species) .

The top canopy of the vegetation in the pure sal forests dominated by Shorea robusta, Pterocarpus marsupium,Terminalia tomentosa, Woodfordia fruiticosa and Diospyros melanoxylon. The second layer was dominated by the Miliusa tomentosa and in the third layer

Proceedings of the International Forestry and Environment Symposium 2010 of the Department of Forestry and Environmental Science, University of Sri Jayewardenepura, Sri Lanka. 
the saplings of Diospyros melanoxylon and Shorea robusta were predominant .Degraded moist deciduous forest site is dominated by shorea robusta, Terminalia tomentosa and Diospyros melanoxylon on sal dominated patches. However, in mixed forest site sal is absent and the forest is dominated by Terminalia tomentosa and Anogeissus latifolia. . The second storey is dominanted by species was miliusa tomentosa, where as in the third layer Diospyros melanoxylon was less pronounced. However, the density and cover of the under storey vegetation was very poor as compared to pure sal forest.

The density, basal cover and IVI for trees and under story layer are given in Table 1 and 2 respectively. The total basal cover of trees and Under story was $36.36 \mathrm{~m}^{2} \mathrm{ha}^{-1}, 1.85 \mathrm{~m}^{2} \mathrm{ha}$ ${ }^{1}$ respectively in pure sal forest and $32.37 \mathrm{~m}^{2} \mathrm{ha}^{-1}, 0.37 \mathrm{~m}^{2} \mathrm{ha}^{-1}$ in degraded forest.

The dominant trees in pure sal forest were Shorea robusta, Terminalia tomentosa and Diospyros melanoxylon(mean IVI 84.97, 37.43 and 24.84 respectively). In Understory the dominant species were Miliusa tomentosa,Embelua robusta, Diospyros melanoxylon and Shorea robusta with mean IVI of 47.72, 46.93, 45.39 and 38.09 respectively.

In degraded forest were Shorea robusta, Terminalia tomentosa and Miliusa tomentosa (mean IVI 104.23, 67.90 and 31.76 respectively). In Understory the dominant species were Miliusa tomentosa,Embelua robusta, Diospyros melanoxylon and Shorea robusta with mean IVI of $112.8,67.5$ and 25.01 respectively.

The complexicity index is product of stem density, canopy height, number of species and basal cover(Holdrige et al.1971).For the present study the mean complexcity index was 13.44 for pure sal forest as compared to5-45 for tropical dry forest and 180-405 for tropical wet forest(Murphy and Lugo1986).This is in conformity to the report of Murphy and Lugo(1986)that dry tropical forest are less complex floristically and structurally then wet tropical forest.

Tree basal cover in the present study varied from 32.37-36.36 $\mathrm{m}^{2}$ ha- for both pure sal forest and degraded moist deciduous sites. These basal cover values were higher than that of the values reported for the several dry tropical forest communities in Vindhyan region by (Jha and Sing 1990) between 6.58-23.21m2ha-1 and by ( Singh and Singh 1991 ) The trotal basal cover in the present study is $32.82-36.36 \mathrm{~m}^{2}$ ha for pure sal forest and degraded moist deciduous sites . These values are in comparision with 17-40 $\mathrm{m} 2$ ha-1 for dry tropical. forest and 20-75 m2ha-1 for wet forest ( Murphy and Lugo 1986) .

In the present study tree density ranged from 1040-1250 stems ha

Proceedings of the International Forestry and Environment Symposium 2010 of the Department of Forestry and Environmental Science, University of Sri Jayewardenepura, Sri Lanka. 
site while the concentration of dominance was higher for degraded moist deciduous sites. The higher concentration of dominance and lower diversity on open forest could be related to uneven show of dominance i.e. case of shorea robusta, show in dominance was maximum as compared to other species. The shanon-wiener index for the tree and shrubs in the prasent study was low 2.66-2.925, ( in pure sal forest) and 1.42-2.36, ( in degraded moist deciduous sites)as compared to tropical rainforest of silent valley (3.8-4.8; singh et al 1984). For the pure sal forest site, the species diversity (Shanon-wiener index)for tree layer was 2.82, and for under story layer it was 2.93compared to Dry Dipterocarp Forest of Thailand(3.754.49,Krratiprayon et al.1995),tropical rain forest of Silent Valley,India3.8-4.8(Singh et al.1984).

Diversity parameters in the tropical pure sal forest communities i.e.trees and under story vegetation 2.82,2.92( shanon-wiener index), 0.99,1.01 ( equatability) 4.76,2.32 ( species richness) ,0.21,0.22(Concentration of Dominance)and 5.78,8.82 ( Beta diversity) respectively .Diversity parameters in tropical forest of the Vindhyan hill as reported by Singh and Singh ( 1991) had ranged between 1.93-2.82 ( Shanon-wienar index), 0.83-1.04 ( equitability) and 0.18-0.39 ( simpson's index) o.88-1.4 ( species richness).Sager et al(2003)reported Shanonwienar index between 1.398-2.629 for dry tropical forest located along the disturbance gradient.

Diversity parameters in the degraded moist deciduous sites communities i.e.trees and under story vegetation are 1.99,2.44( shanon-wiener index), 0.78,1.04 ( equatability) 3.48,1.43 ( species richness) $, 0.39,0.26$ (Concentration of Dominance)and 8.20,11.93. ( Beta diversity) respecively.

Thus from the study of diversity and species composition of sal dominated tropical moist deciduous forest it is evident that the sal dominated forests site is highly diverse than miscellaneous degraded moist deciduous forest in all aspect. This indicates that the climatic condition of Chhattisgarh region would have favorable sal and its associates in the climax formation over a long successional process and have favored highly diverse forest of sal. Therefore, the management plan for this forest should focus on sal and its associates in order to safeguard the overall diversity of this area.

\section{REFERENCES}

Bruenig, E.F. 1983. Vegetation structure and growth. Pages 44-75, In: Golley, F.B. (Editor) Tropical ainforest Ecosystems: structure and Function. Elsevier Scientific Publishing. Amsterdam.

Curtis, J.T. and McIntosh, R.P. 1950. The interrelations of certain analytic and synthetic phytosociological characters. Ecology 31: 434-455.

EPCO, 1999. Amarkantak Biosphere Reserve; Project Document. Environmental Planning and Coordination Organization, Bhopal - 462016.

Holdridge, L.R., Grenke, W.C., Hatheway, W.H., Liang, T. and Tosi, Jr. J.A. 1971. Forest Environments in Tropical Life Zones, A Pilot Study Pergamon Press, New York. 747 pages.

Howkins, B.A. (2010) Ecology's oldest patlerns? Trends in ecology \& Evolution 16:470 .

Jha, C.S. 1991. Land Ue and Vegetation Analysis of a Dry Tropical Forest Region. Ph. D. Thesis, Banaras Hindu University, Varanasi.

Jha, C.S. and Singh J.S.1990. Composition and dynamics of dry tropical forest in relation to soil texture. Journal of Vegetation Science 1:609-614.

Proceedings of the International Forestry and Environment Symposium 2010 of the Department of Forestry and Environmental Science, University of Sri Jayewardenepura, Sri Lanka. 
Jordan, C.F. 1983. Productivity of tropical rainforest ecosystems and the implications for their use as future wood and energy sources. Pages 117-136, In: Golley, F.B. (Editor) Troppical Rain Forest Ecosysterms: Structure and Function. Elsevier Scientific Publishing, Amsterdam.

Kaul, O.N. and Sharma, D.C. 1971. Forest type statistics. Indian Forester 97: 432-436.

Kershaw, K.R. 1973. Quantitative and Dynamic Plant Ecology. Edward Arnold, London. 308 pages.

Kiratiprayoon, J., Luangjame, S., Damrongthai, P. and Tarumastsawas, M. 1995. Species diversity of the second growth at ngao Demonstration Foprest, Lampang Province. Pages 237-245, In:Boyle T.J.B. and Boontawee. B. (Editors) Measuring and Monitoring

Biodiversity in Tropical and Temperate Forests. Centre for International Forestry Research, Bogor, Indonesia.

Margalef, R. 1958. Information theory in ecology. General Systematics 3: 36-71.

May, R.M. and Stumpf, M.P.H. 2000. Species area relations in tropical forests. Science 290: 2084 2086.

Misra, R. 1986. Ecology Workbook. Oxford and IBH Publishing. Calcutta. 244 pages.

Murphy, P.G. and Lugo, A.E. 1986. Ecology of tropical dry forest. Annual Review of Ecology and Systematics 17: 67-88.

Phillips, E.A. 1959. methods of Vegetation Study. Holt, Rinehart and Winston, New York. 107 pages.

Pielou, E.C. 1966. the measurement of diversity in different types of biological collections. Journal of Theoretical Biology 13: 131-144.

Pitman, N.C.A., Terborgh. J.W., Silman, M.R., Percy, N.V., Neill, D.A., Ceron C.E., Palacios, W.A. and Aulestia, M. 2002. a comparison of tree species diversity in two upper Amazopnian forest Ecology 83: 3210-3224.

Prakash, R. 1992. wild Life Working Plan. IInd Preliminary Proposal. Forest Department, Govt. of M.P., Bhopal.

Sagar, R and Singh, J.S. 1999. species diversity and its measurement. The Botanica 49: 9-16.

Sagar, R., Raghubanshi, A.S. and Singh, J.S. 2003. Asymptotic models of species area curve for measuring diversity of dry tropical forest tree species. Current Science 84: 1555-1560.

Shannon,C.E. and Weaver, W. 1963. the Mathematical Theory of Communications. University of Illinios Press, Urbana. 117 pages.

Simpson. E.H. 1949. measurement of diversity Nature 168-688.

Singh J.S., Singh, S.P., Saxena, A.K. and Rawat, Y.S. 1984. The forest vegetation of Silent Valley, India. Pages 25-52. In: Chadwick, A.C. and Sutton, S.L. (Editors) Tropical Rain Forest. The Leeds Sympsium, Leeds Philosophical and Literary Society, Leeds, U.K.

Singh, Laliji and Singh, J.S. 1991. species structure dry matter dynamics and carbon flux of a dry tropical forest in India. Annals of Botany 68: 263-273.

Smith, R.L. 1974. Ecology and field Biology. Harper and Row, New York. 850 pages.

UNEP, 2002 Repont on the sixth meeting 9 the contaenec of the parties to the convention on

Biologycal Divaety (OMEP/CBD/COP/ 20/PART 2) strategic plan Decision VI/26 , Convention on Bilogical Deversity.

Whitmore, T.C. 1984. Tropical Rain Forest of Far East. $2^{\text {nd }}$ edition. Claredon Press, London.

Proceedings of the International Forestry and Environment Symposium 2010 of the Department

of Forestry and Environmental Science, University of Sri Jayewardenepura, Sri Lanka. 
Whittaker, R.H. 1972. Evolution and measurement of species diversity. Taxon 21: 213-251.

Table 3. Diversity parameters of sal dominated and degraded moist deciduous forest

Parameters

Species richness $(d)$

$\mid$

a)

b)
Sal Dominated

Forest
Degraded Moist

Deciduous Forest 
Table 1: Species structure of the tropical moist deciduous forest (tree layer)

\begin{tabular}{|c|c|c|c|c|c|c|}
\hline \multirow[t]{2}{*}{ Species } & \multicolumn{3}{|c|}{$\begin{array}{c}\text { Sal Forest } \\
\end{array}$} & \multicolumn{3}{|c|}{ Degraded Forest } \\
\hline & $\begin{array}{c}\text { Density } \\
\left(\text { stems ha }^{-1}\right)\end{array}$ & $\begin{array}{c}\text { Basal cover } \\
\left(\mathbf{m}^{2} \mathbf{h a}^{-1}\right)\end{array}$ & IVI & $\begin{array}{c}\text { Density } \\
\left(\text { stems ha }^{-1}\right)\end{array}$ & $\begin{array}{c}\text { Basal cover } \\
\left(\mathbf{m}^{2} \mathbf{h a}^{-1}\right)\end{array}$ & IVI \\
\hline Shorea robusta Gaertn f. Dipterocarpacear & 350 & 14.24 & 84.97 & 233 & 15.66 & 104.23 \\
\hline $\begin{array}{l}\text { Terminalia tomentosa Wt \& Agn. } \\
\text { Combretaceae }\end{array}$ & 140 & 4.98 & 37.43 & 133 & 7.96 & 67.9 \\
\hline $\begin{array}{l}\text { Diospyros melanoxylon Roxb. } \\
\text { Ebenaceae }\end{array}$ & 117 & 2.0 & 24.84 & 27.0 & 3.23 & 19.11 \\
\hline $\begin{array}{l}\text { Embelia robusta C.B. Clarke non Roxb. } \\
\text { Myrsinaceae }\end{array}$ & 143.0 & 1.59 & 21.43 & - & - & - \\
\hline $\begin{array}{l}\text { Miliusa tomentosa (Roxb.) J. Sinclair, } \\
\text { Annonaceae }\end{array}$ & 107.0 & 0.73 & 20.52 & 90.0 & 0.64 & 31.76 \\
\hline Pterocarpus marsupium Roxb. Fabaceae & 40.0 & 3.31 & 18.78 & 7.0 & 0.12 & 3.54 \\
\hline Buchanania lanan Spreng, Anacardiaceae & 80.0 & 1.32 & 17.97 & 27.0 & 0.47 & 11.58 \\
\hline $\begin{array}{l}\text { Anogeissus latifolia Wall.ex Bedd, } \\
\text { Combretaceae }\end{array}$ & 27.0 & 1.10 & 10.45 & 20.0 & 1.74 & 13.46 \\
\hline Woodfordia fruticosa Lythraceae & 10.0 & 1.73 & 6.17 & - & - & - \\
\hline Eugenia cumini Druce, Myrtaceae & 17.0 & 0.80 & 6.10 & - & - & - \\
\hline $\begin{array}{l}\text { Ougeinia oojeinensis (Roxb.) Hochr. } \\
\text { Fabaceae }\end{array}$ & 23.0 & 0.44 & 5.61 & 10.0 & 0.22 & 4.31 \\
\hline Lannea grandis Engl. Anacardeaceae & 13.0 & 0.9 & 5.45 & 7.0 & 0.14 & 3.60 \\
\hline Emblica officinalis Gaertn, Euphorbiaceae & 27.0 & 0.19 & 5.26 & 7.0 & 0.28 & 4.31 \\
\hline Dendrocalamus strictus Nees Poaceae & 17.0 & 0.32 & 4.79 & - & - & - \\
\hline Grewia tiliacfolia Vahl., Tiliaceae & 20.0 & 0.36 & 4.57 & - & - & - \\
\hline $\begin{array}{l}\text { Radermachera xylocarpa Roxb. K. Schum } \\
\text { Bignoniaceae }\end{array}$ & 10.0 & 0.50 & 4.12 & 7.0 & 0.27 & 3.99 \\
\hline Careya arborea Roxb. Lecythidaceae & 7.0 & 0.62 & 2.86 & 7.0 & 0.16 & 2.48 \\
\hline Zizyphus xylopyra Willd, Rhamnaceae & 7.0 & 0.26 & 2.64 & 3.0 & 0.02 & 1.41 \\
\hline Bridelia squamosa Gehrm, Euphorbiaceae & 7.0 & 0.12 & 2.26 & 3.0 & 0.36 & 2.44 \\
\hline Lagerstroemia parviflora Roxb. & 7.0 & 0.09 & 2.18 & 3.0 & 0.05 & 1.5 \\
\hline $\begin{array}{l}\text { Bauhinia malabarica Roxb. } \\
\text { Caesalpiniaceae }\end{array}$ & 7.0 & 0.07 & 2.12 & 3.0 & 0.07 & 1.56 \\
\hline Terminalia chebula Retz. Combretaceae & 3 & 0.31 & 1.69 & - & - & - \\
\hline $\begin{array}{l}\text { Mitragyna parvifolia (Roxb.) Korth, } \\
\text { Rubiaceae }\end{array}$ & 3.00 & 0.14 & 1.21 & - & - & - \\
\hline Cordial dichotoma Forst. F. Boraginaceae & 3.00 & 0.06 & 0.99 & - & - & - \\
\hline Ficus religiosa Linn. Moraceae & 3.00 & 0.06 & 0.99 & - & - & - \\
\hline $\begin{array}{l}\text { Semecarpus anacardium Linn. F. } \\
\text { Anacardiaceae }\end{array}$ & 3.0 & 0.04 & 0.94 & - & - & - \\
\hline $\begin{array}{l}\text { Adina cordifolica Benth \& Hok. F. } \\
\text { Rubiaceae }\end{array}$ & 3.0 & 0.03 & 0.91 & 10.0 & 0.57 & 6.26 \\
\hline $\begin{array}{l}\text { Bauhinia vahlii Wight \& Arn. } \\
\text { Caesalpiniaceae }\end{array}$ & 3.0 & 0.02 & 0.88 & - & - & - \\
\hline Cassia fistula Linn. Caesalpiniaceae & 3.00 & 0.02 & 0.88 & - & - & - \\
\hline Kydia calycina Roxb. Malvacea & 3.00 & 0.01 & 0.87 & 10.0 & 0.17 & 2.98 \\
\hline Tectona grandis Linn. F. Verbenaceae & - & - & - & 13.0 & 0.21 & 6.51 \\
\hline Madhuca indica J.F.Gmel. Sapotaceae & - & - & - & 7.0 & 0.18 & 3.72 \\
\hline Dalbergia paniculata Roxb. Fabaceae & - & - & - & 3.0 & 0.02 & 1.41 \\
\hline Burseraceae & - & - & - & 3.0 & 0.28 & 2.20 \\
\hline Total & 1203 & 36.36 & & 633 & 32.82 & \\
\hline
\end{tabular}

Note: All data are average of three plots

Proceedings of the International Forestry and Environment Symposium 2010 of the Department of Forestry and Environmental Science, University of Sri Jayewardenepura, Sri Lanka. 
Table 2; Species structure of the tropical moist deciduous forest (unerstorey layer)

\begin{tabular}{|c|c|c|c|c|c|c|}
\hline \multirow[t]{2}{*}{ Species } & \multicolumn{3}{|c|}{ Sal Dominated Forest } & \multicolumn{3}{|c|}{$\begin{array}{c}\text { Degraded Moist Deciduous } \\
\text { Forest }\end{array}$} \\
\hline & $\begin{array}{c}\text { Density } \\
\text { (stems ha } \\
\text { 1) }\end{array}$ & $\begin{array}{c}\text { Basal } \\
\text { cover } \\
\left(\mathrm{m}^{2} \mathrm{ha}^{-1}\right)\end{array}$ & IVI & $\begin{array}{c}\text { Density } \\
\text { (stems ha } \\
1 \text { 1) }\end{array}$ & $\begin{array}{c}\text { Basal } \\
\text { cover } \\
\left(\mathbf{m}^{2} \mathbf{h a}^{-1}\right)\end{array}$ & IVI \\
\hline Maliusa tomentosa & 230.0 & 0.33 & 47.72 & 317.0 & 0.19 & 112.81 \\
\hline Embelia robusta & 397.0 & 0.24 & 46.93 & 53.0 & 0.01 & 15.59 \\
\hline Diospyros melanoxylon & 187.0 & 0.39 & 45.39 & 277.0 & 0.5 & 67.51 \\
\hline Shorea robusta & 247.0 & 0.16 & 38.09 & 87.0 & 0.02 & 25.11 \\
\hline Ventillago calyculata Tul. Rhamnaceae & 30.0 & 0.39 & 25.82 & 10.0 & 0.01 & 4.72 \\
\hline Eugenia cumini & 157.0 & 0.08 & 20.85 & 23.0 & 0.01 & 8.3 \\
\hline Emblica officinalis & 23.0 & 0.05 & 8.52 & 7.0 & 0.01 & 4.39 \\
\hline Grewia tiliaefolia & 40.0 & 0.05 & 8.07 & - & - & - \\
\hline Bauhinia vahlaii & 33.0 & 0.004 & 6.67 & - & - & - \\
\hline $\begin{array}{l}\text { Schleichera oleosa (Lour.) Oken, } \\
\text { Sapindaceae }\end{array}$ & 27.0 & 0.008 & 5.90 & 17.0 & 0.002 & 7.56 \\
\hline Heretic laevis Roxb. Boraginaceae & 23.0 & 0.01 & 4.83 & - & - & - \\
\hline Buchanania lanzan & 20.0 & 0.02 & 3.88 & 17.0 & 0.02 & 11.27 \\
\hline Terminalia tomentosa & 10.0 & 0.03 & 3.79 & 3.0 & 0.0003 & 2.07 \\
\hline Cassia fistula & 17.0 & 0.004 & 3.48 & 7.0 & 0.001 & 3.2 \\
\hline Lagerstoemia parviflora & 10.0 & 0.01 & 3.36 & 10.0 & 0.005 & 3.37 \\
\hline Ptcrocarpus marsupium & 7.0 & 0.02 & 3.06 & - & - & - \\
\hline Radcrmachera xylocarpa & 7.0 & 0.02 & 3.06 & - & - & - \\
\hline Adina cordifolia & 17.0 & 0.007 & 2.99 & - & - & - \\
\hline Grevia hirsute vah. Tiliaceae & 17.0 & 0.0004 & 2.63 & - & - & - \\
\hline Madhuca indica & 1.0 & 0.0004 & 2.19 & 7.0 & 0.0001 & 2.96 \\
\hline Smilex macrophylla Roxb. Liliaceae & 7.0 & 0.0007 & 2.02 & - & - & - \\
\hline Helicteres isora Linn. Sterculiaceae & 13.0 & 0.0003 & 1.50 & - & - & - \\
\hline Terminalia chebula & 7.0 & & 1.48 & - & - & - \\
\hline Indigofera pulchella Roxb. Fabaceae & 10.0 & 0.003 & 1.45 & - & - & - \\
\hline Semecarpus anacardium & 30.0 & 0.007 & 1.22 & - & - & - \\
\hline Ziziphus xylopyra & 30.0 & 0.007 & 1.22 & - & - & - \\
\hline Anogeissus latifolia & 7.0 & 0.001 & 1.15 & - & - & - \\
\hline Randia uliginosa Dc. Ribiaceae & 7.0 & 0.00007 & 1.10 & - & - & - \\
\hline Dillenia aurea Sm. Dilleniaceae & 3.0 & 0.0002 & 0.86 & - & - & - \\
\hline Gardenia turgida Roxb. Rubiaceae & 3.0 & 0.0003 & 0.86 & - & - & - \\
\hline Tectona grandis & - & - & - & 30.0 & 0.02 & 11.77 \\
\hline $\begin{array}{l}\text { Aegle marmelos Correa ex. Roxb. } \\
\text { Rutaceae }\end{array}$ & - & - & - & 30.0 & 0.007 & 7.33 \\
\hline Ziziphus ocnoplia Mill. Rhamnaceae & - & - & - & 10.0 & 0.0007 & 3.45 \\
\hline Garuga pinnata & - & - & - & 3.0 & 0.007 & 3.15 \\
\hline Boswellia serrata Roxb. Burseracae & - & - & - & 7.0 & 0.0001 & 2.96 \\
\hline Wendlandia exserta Dc. Rubiaceae & - & - & - & 3.0 & 0.0007 & 1.45 \\
\hline Total & 1572 & 1.85 & & 918 & 0.37 & \\
\hline
\end{tabular}

Proceedings of the International Forestry and Environment Symposium 2010 of the Department of Forestry and Environmental Science, University of Sri Jayewardenepura, Sri Lanka. 